\title{
Tectorial Membrane and Otolithic Membrane of Pigeon Inner Ear. A Scanning Electron Microscope Study*
}

\author{
Tomoyuki HosHino
}

\author{
Received November 8, 1972
}

Summary. The tectorial membrane and otolithic membrane of pigeon inner ear were observed by scanning electron microscopy. Special attention was paid to the possible connection of sensory cells to the membranes.

1. Each hair bundle of the sensory cells of the cochlea was enclosed in a cavity on the under side of the tectorial membrane, the longest hairs being attached directly to the cavity rim. A fine fibrillar structure on the supporting cells of the cochlea was directly connected to the cavity rim of the tectorial membrane.

2. Each sensory hair bundle of the vestibular maculae was surrounded by fine fibrils and projected upwards into a cavity on the lower surface of the otolithic membrane. A connection between the hair tips and the otolithic membrane could not be evidenced, though both elements were supposed to be in contact with each other through the fibrillar structures on the supporting cells of the vestibular maculae.

The contact between sensory cells and the overlying gelatinous membranes in the inner ear has been investigated for clarification of the mechano-electrical transducing mechanism in the sensory end-organs. Such a relationship in the inner ear of the bird, mainly in the cochlea, has previously been studied by light and transmission electron microscopes (TEM) (HELD, 1926; JAHNKE, LUNDQUIST and WERSÄLL, 1969; Rosenhall, 1970; TAKasaka and Smith, 1971; Dohlman, 1971). Recent application of the scanning electron microscope (SEM) to the biological field is adding new insights to hitherto known facts which have been accumulated through the classical studies.

In the present study the tectorial membrane and the otolithic membrane and their way of contacting the sensory cells in the inner ear of the pigeon have been investigated by the SEM. The cupula of the crista ampullaris has been omitted from this study because of its marked disfigurement during preparation procedures; entirely different techniques seem necessary for the preservation of this characteristically fragile structure.

\section{Materials and Methods}

Adult domestic pigeons weighing 300-470 g were anesthetized with pentobarbital. After removal of the columella, $2 \%$ glutaraldehyde in $0.1 \mathrm{M}$ phosphate buffer ( $\mathrm{pH} 7.3$ ) was gently perfused through the oval window and small bony openings in the semicircular canals. Following decapitation, the temporal bone was trimmed and further fixed in the glutaraldehyde solution for 5-12 hrs. The specimens were post-fixed in phosphate buffered osmium tetroxide $(1 \%)$ for $1 \mathrm{hr}$, further trimmed in $70 \%$ alcohol under an operating microscope and dehydrated in an ascending series of alcohol.

*This study was aided by U. S. P. H. S. Research Grant No. NS 10412 
After dehydration, the specimens were placed in a few changes of amyl acetate for about 20-30 min. ANDERSON's (1951) critical point drying method using carbon dioxide (modification by TANAKa, 1972) was applied in most cases. Some specimens were also dried in open air.

Observation was made with a Hitachi SSM-type II scanning electron microscope at magnifications of $100-10,000$ times.

\section{Results}

\section{Structure of the tectorial membrane and the sensory cells}

The tectorial membrane stretched over the hair cell region from the medial insertion at the tall cylindrical cells (the limbic epithelium) to the lateral end of the hair cell region. The endolymphatic or upper surface was reticular in structure (Fig. 1). Parallel rows of thick smooth fascicles were connected by crossing thinner fascicles. The surface of these fascicles appeared smooth and not fibrillar or filamentous in this preparation. Thick fascicles ran antero-laterally or obliquely to the axis of the cochlea at the basal and middle portion, but almost transversely at the apical portion.

The cross section of the tectorial membrane was a flat triangle, thick at the medial and thin at the lateral end. The section revealed numerous holes resembling a Swiss cheese (Fig. 2). They were found to be more numerous in the lower part, fewer in number toward the upper surface with none at all at the medial inserting portion of the membrane. These holes seemed to represent a section of a canal network inside the tectorial membrane. The canals appeared to open out onto the upper and lower surfaces.

The lower surface, which faced the hair cells, was composed of deep cavities with smooth walls (Fig. 3). The rims of the walls were fringed with a fine cottony substance (Fig. 4). Proceeding from the medial to the lateral edge of the membrane, the walls of the cavities tended to flatten out towards the direction of the lateral edge. Each cavity had one or more round holes which were connected to the canal system inside the membrane (Fig. 2). Toward the lateral end, or thinnest portion of the tectorial membrane, there were small round holes in place of the cavities (Fig. 4-A). Due to the gradual flattening out of the cavity walls, there were no cavities any more. However, the cottony substance retained its circular distribution corresponding to the cavity structure.

Under higher magnification, sensory hairs were seen to be attached to the lower surface of the tectorial membrane (Fig. 4). These hairs, which were torn from the upper surface of the sensory cells during preparation, grouped as single rows along the rim of the cavity wall. In some places, instead of the sensory hairs themselves, shallow dots were found indicating the points of insertion of the hair tips to the tectorial membrane (Fig. 4-B arrows). A fine cottony substance covered the lateral surface of the hairs.

The hair cells on the basilar papilla (identical with the organ of Corti in mammals) are distributed over the basilar membrane and show no differentiation into inner and outer hair cells such as found in mammals. The hair cells were surrounded by narrow hems of supporting cells (Fig. 5). The surface of the supporting cells had many microvilli and were covered by a fine web-like structure in contrast to the flat, 


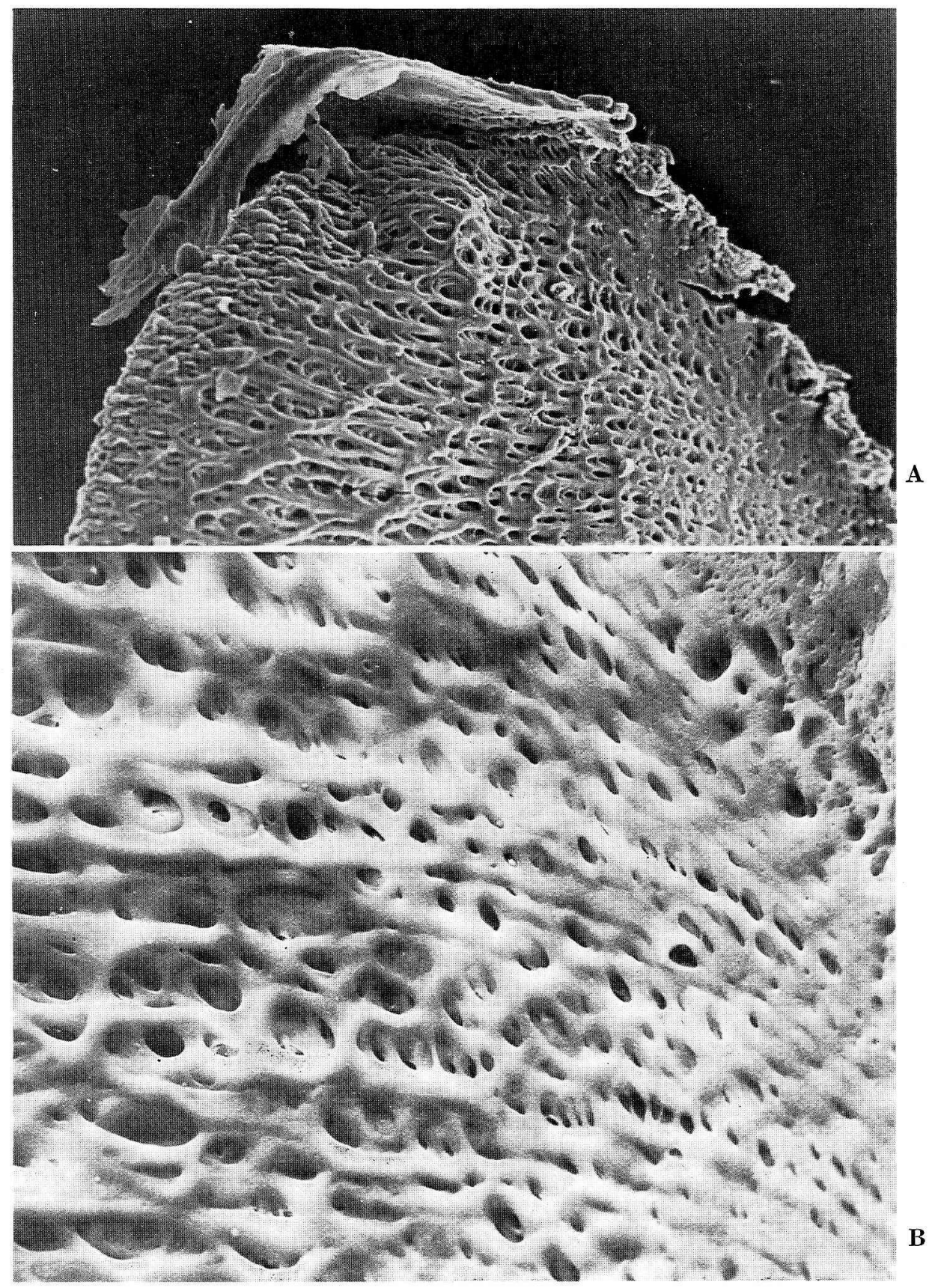

Fig. 1. Upper surface of the tectorial membrane of the pigeon. Apical portion (A) and middle portion (B) of the left cochlea. The tectorial membrane stretches from the inserting point at the limbic epithelia (right-hand side in the picture). Thick fascicles run antero-laterally in $\mathbf{B}$ but they run almost rectangularly in $\mathbf{A} . \mathrm{A}: \times 570 \quad$ B: $\times 2,300$ 
smooth surface of the hair cells. These fine fibrils appeared to be the same substance which showed circular distribution along the rims of the cavities on the lower surface of the tectorial membrane. Without doubt they connected the rims of the cavities and the surfaces of the supporting cells but were torn apart when the tectorial membrane was prepared for observation.

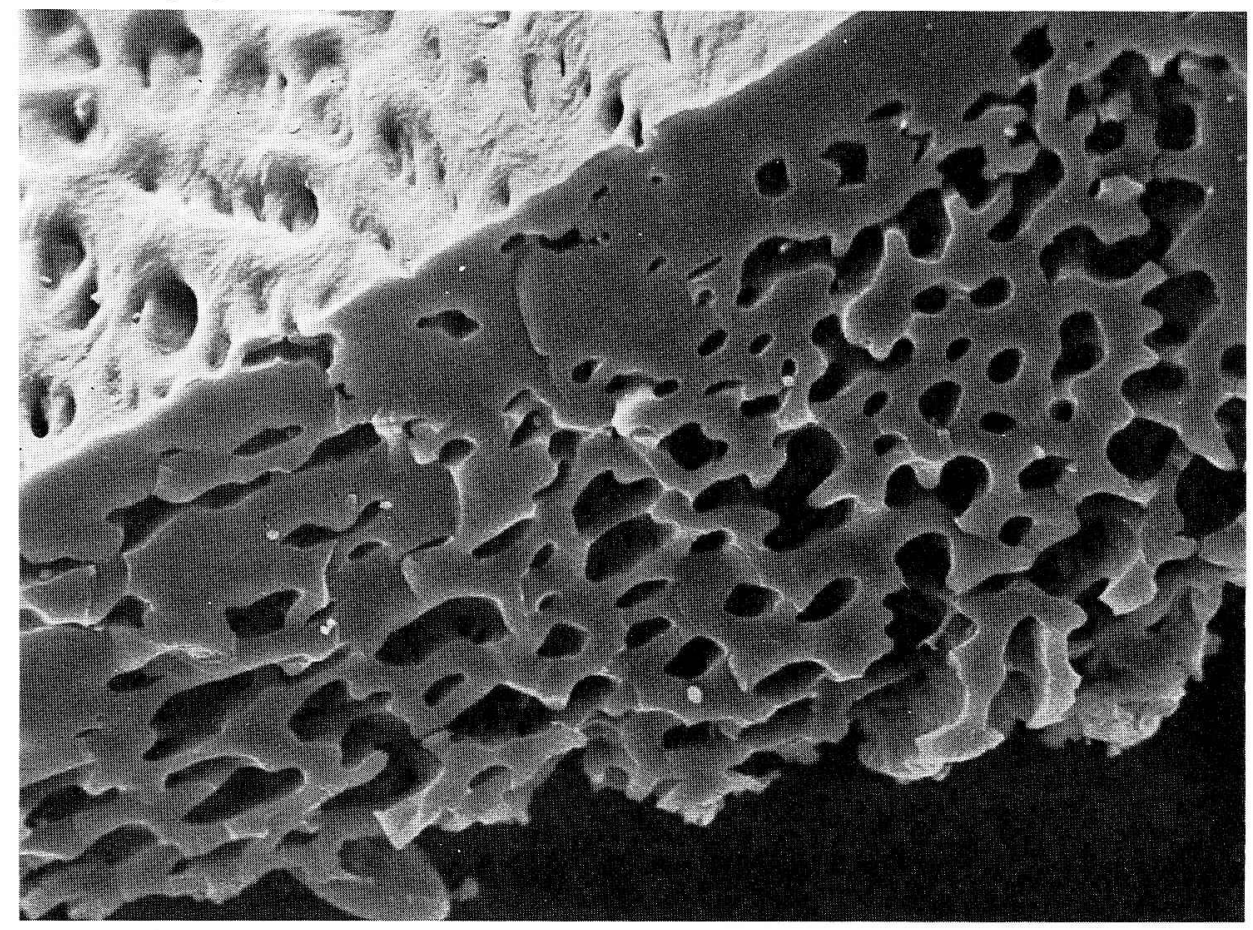

Fig. 2. Cross section of the tectorial membrane. Note the many holes and canaliculi, more numerous in the lower portion. The cross section is a triangular shape, thin at the lateral edge and thick towards the medial portion or the site of insertion in the medial wall (right-hand side in the picture). $\times 2,300$

The hair bundles were not situated in the center of the cells but on their lateral periphery. In a single sensory hair grouping, the heights of the hairs increased from the medial to the lateral end. Adjacent to the longest hair on the lateral edge was a kinocilium of similar length. It was exposed by removing the fibrillar substance covering the lateral surface of the longest hairs (Fig. 5, insertion). In some cells the outermost line of sensory hairs was found to have been pulled out. As mentioned above, these hairs were found to line up on the lower surface of the tectorial membrane.

Sensory cell surfaces where all the hairs were removed revealed the bases of stereocilia and kinocilium arranged in a thick $\mathrm{V}$ shape. In one micrograph, the hairs were counted; 91 in 7 rows on one cell and 86 in 8 rows on another cell.

\section{Structure of the otolithic membrane and the sensory cells}

As the otolithic membranes of the maculae utriculi and sacculi were similar in structure, the findings are described together here. 


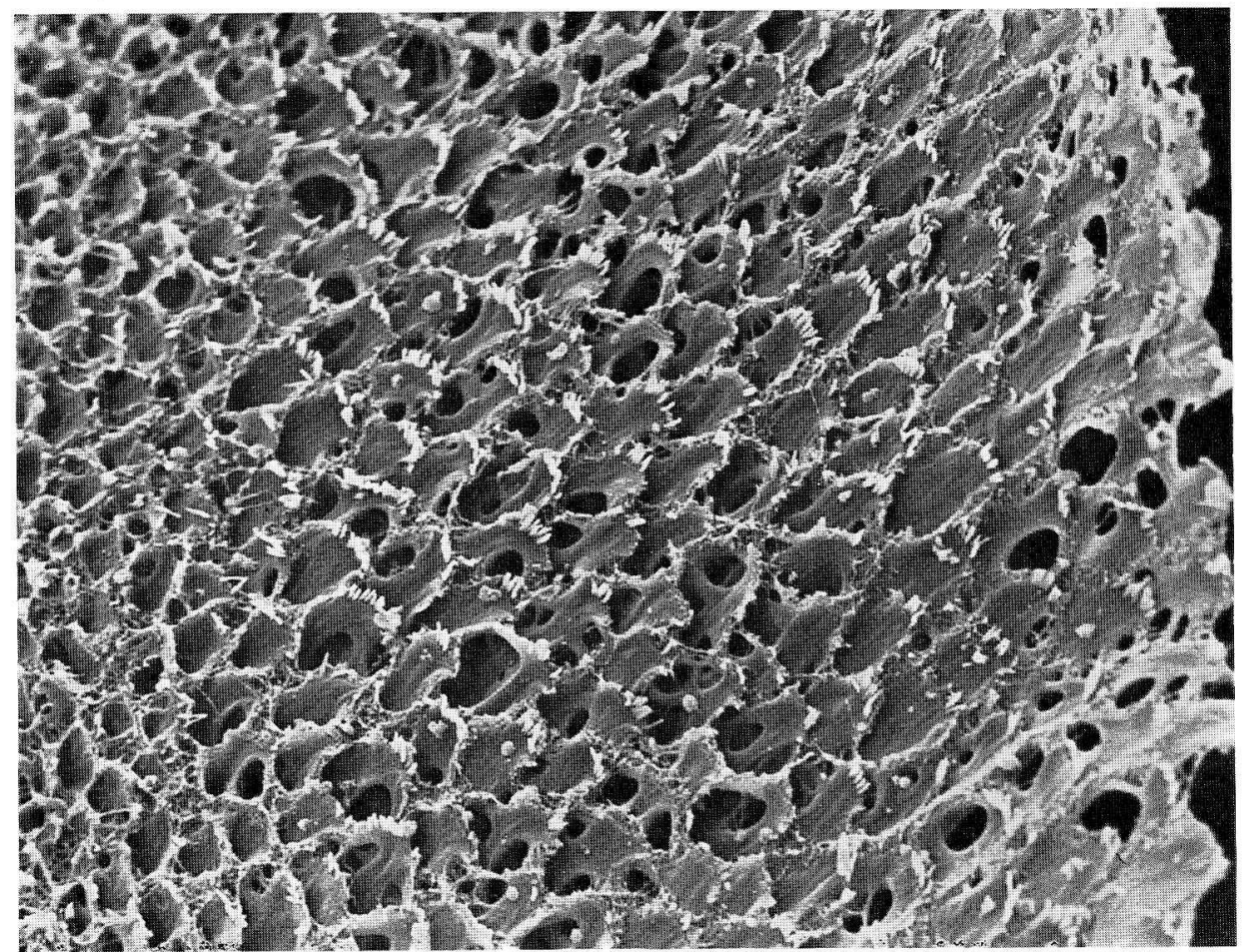

Fig. 3. Low power view of the lower surface of the tectorial membrane. The thick inserting portion with deep cavities is seen on the left and the lateral portion with shallow cavities is seen on the right. $\times 1,200$

The upper surface of the otolithic membrane was found to consist of a thick accumulation of statoconia (Fig. 6). The statoconia were rice-shaped crystals with three facets at each end. The otoliths varied in size, larger ones being almost 10 times the size of smaller ones. They seemed to be connected to each other with thin thread-like structures. The structure appeared to fasten the statoconia to the thick gelatinous layer underneath. This thick layer seemed to separate the layer of statoconia from the sensory cell hairs.

The cross section of the otolithic membrane seemed to be an even height throughout the central portion thinning out at the periphery.

The lower surface of the otolithic membrane, accordingly, differed in structure at the central and peripheral portions. The central portion revealed many cavities (Fig. 7), which did not occur around the periphery due to the thinning out of the otolithic membrane. The peripheral portion was composed of fine gelatinous threads which formed mesh-like structures at some places and were fused into solid masses at other places.

The cavities themselves had smooth continuous walls with occasional small perforations in them. In some instances, the wall was made up of thick homogeneous rods instead of the smooth wall. The rim of the cavities were covered by fine fibrillar structures. 


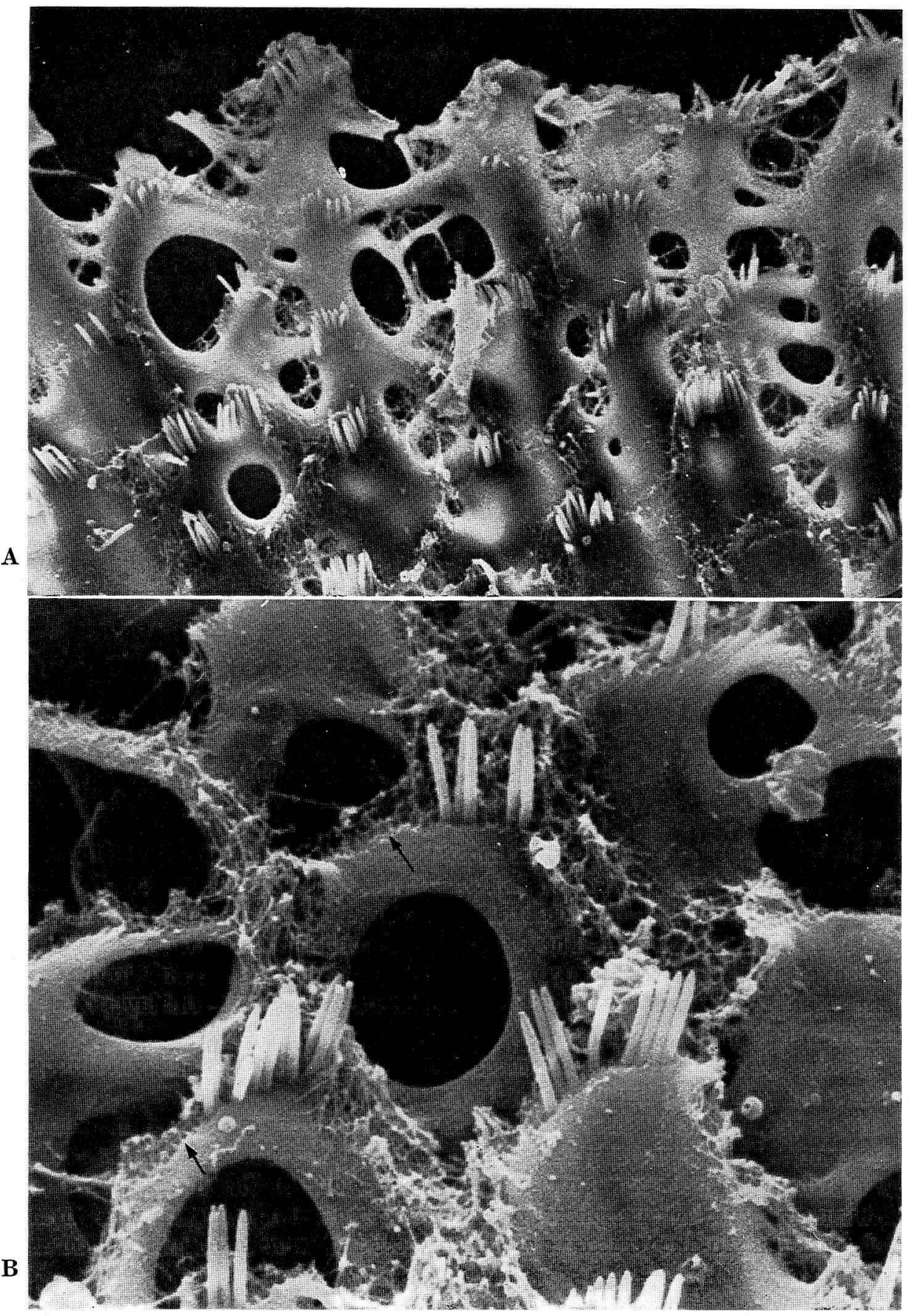

Fig. 4. Higher magnification pictures of Fig. 3. The lateral edge is on the top in these pictures. Picture A shows that the lateral free end of the tectorial membrane is irregularly perforated. Note the circular distribution of the fibrils. At the lateral edge of the circles, sensory hairs are seen arranged in single row groupings. Picture $\mathbf{B}$ shows the middle portion of the lower surface of the tectorial membrane. The cavities have large holes which are the openings of the canal network inside the membrane. Arrows show imprints indicating insertion points of sensory hair tips. A: $\times 2,300 \quad$ B: $\times 5,700$ 
The surface of the macula utriculi revealed the hair bundles of the sensory cells (Fig. 8). The smooth surfaces of the hair cells were surrounded by many short microvilli with a fine fibrillar structure. This fibrillar structure appeared to be the same material as was found on the cavity rims on the lower surface of the otolithic membrane. The fibrillar substance was thus believed to have connected the otolithic membrane and the surfaces of the vestibular maculae but the connection was torn during preparation. A small amount of the same fibrillar substance covered the hair bundles of the sensory cells. Borders between the sensory and supporting cells were

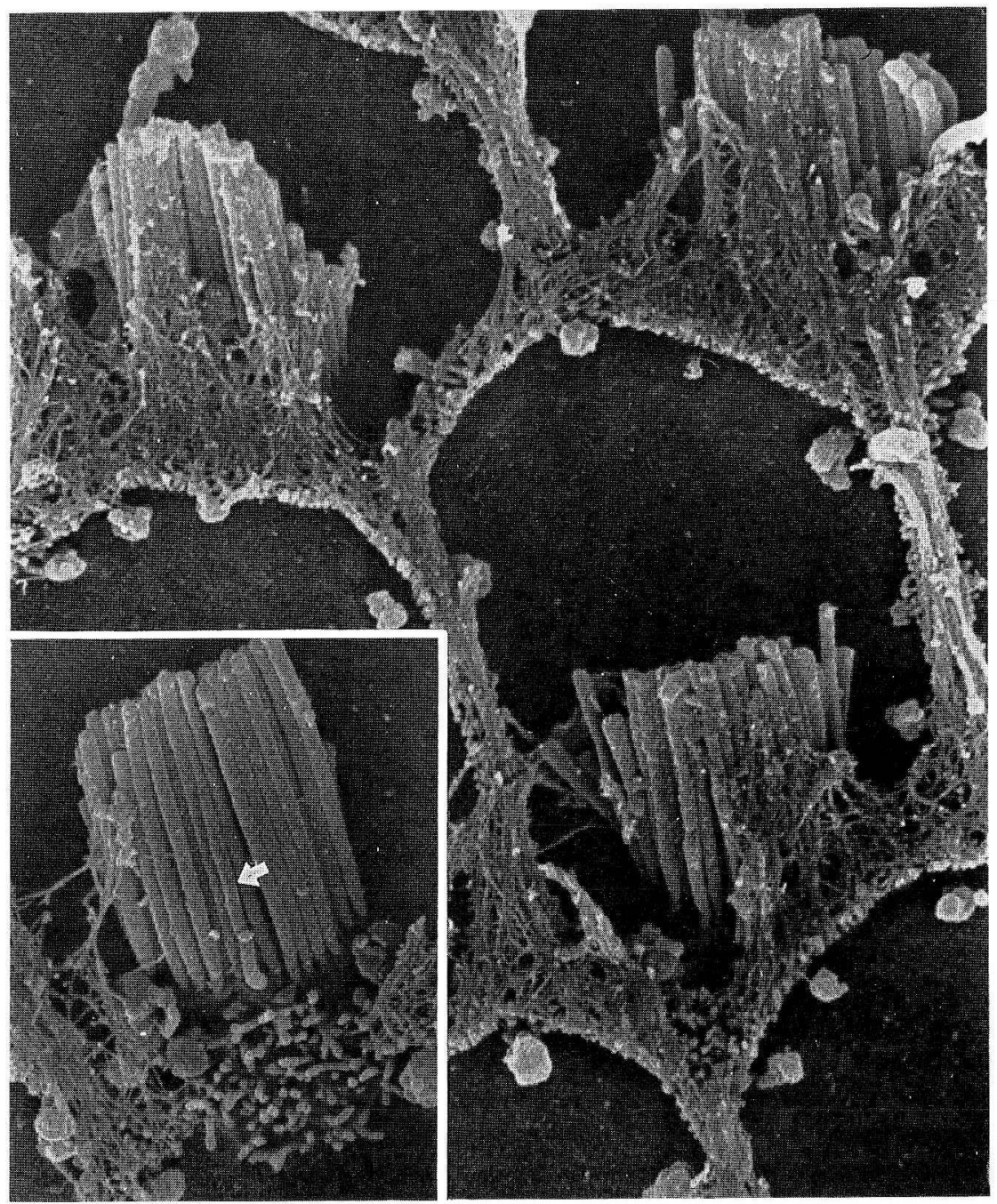

Fig. 5. Surface view of the sensory cells of the cochlea. The lateral surface of the sensory hairs is covered by fine fibrils which are situated on many microvilli of the supporting cells. The nature of the spherical structures on the flat surface of the sensory cells is not known. The insertion shows a kinocilium (arrow) next to the longest stereocilia and the microvilli of the supporting cells. $\times 5,700$ 
not distinct because of the fibrillar covering on microvilli. The hairs on a single sensory cell increased in length from one side to the other with a kinocilium located adjacent to the longest stereocilia. Each cell has the same arrangement of hairs in one direction Hair length increased in the same direction in most cells. Only a few cells revealed hair length increasing in atypical directions.



Fig. 6. Upper surface of the utricular otolithic membrane showing many statoconia. There are strings connecting the statoconia. $\times 2,300$

\section{Comments}

The surface of the tectorial membrane of the cochlea in birds had a reticular appearance as opposed to the tectorial membrane of mammals which has a rather smooth appearance. Dohlman (1971) stated that the holes found on the upper surface of the tectorial membrane of the pigeon were probably the result of the melting effects of lysosome enzymes having fallen down from the light cells in the overhanging tegmentum vasculosum. However, the regularity of the reticular pattern on the surface as found in the present SEM study seems to deny the effect of arbitrarily falling lysosomes from the tegmentum vasculosum. These holes might rather be the result of the regular arrangement of the fine filament of about $90 \AA$ thick as found in a previous TEM study (Iurato, 1960). Dohlman also suggested that the holes inside the tectorial membrane might have been caused by digestive processes created by the same enzymes expelled from the limbic epithelial cells or "long slender cells." The 
distribution pattern of the holes, as mentioned in "Results," suggests that the holes were not the product of digestive processes but a cross section of a canal system created by the regular arrangement of the bundles of fine filaments. DoHLMAN further postulated that the inside holes did not generally communicate with the endolymph. From the present study one may conclude that the endolymph communicates freely with the subtectorial space through the canal system.

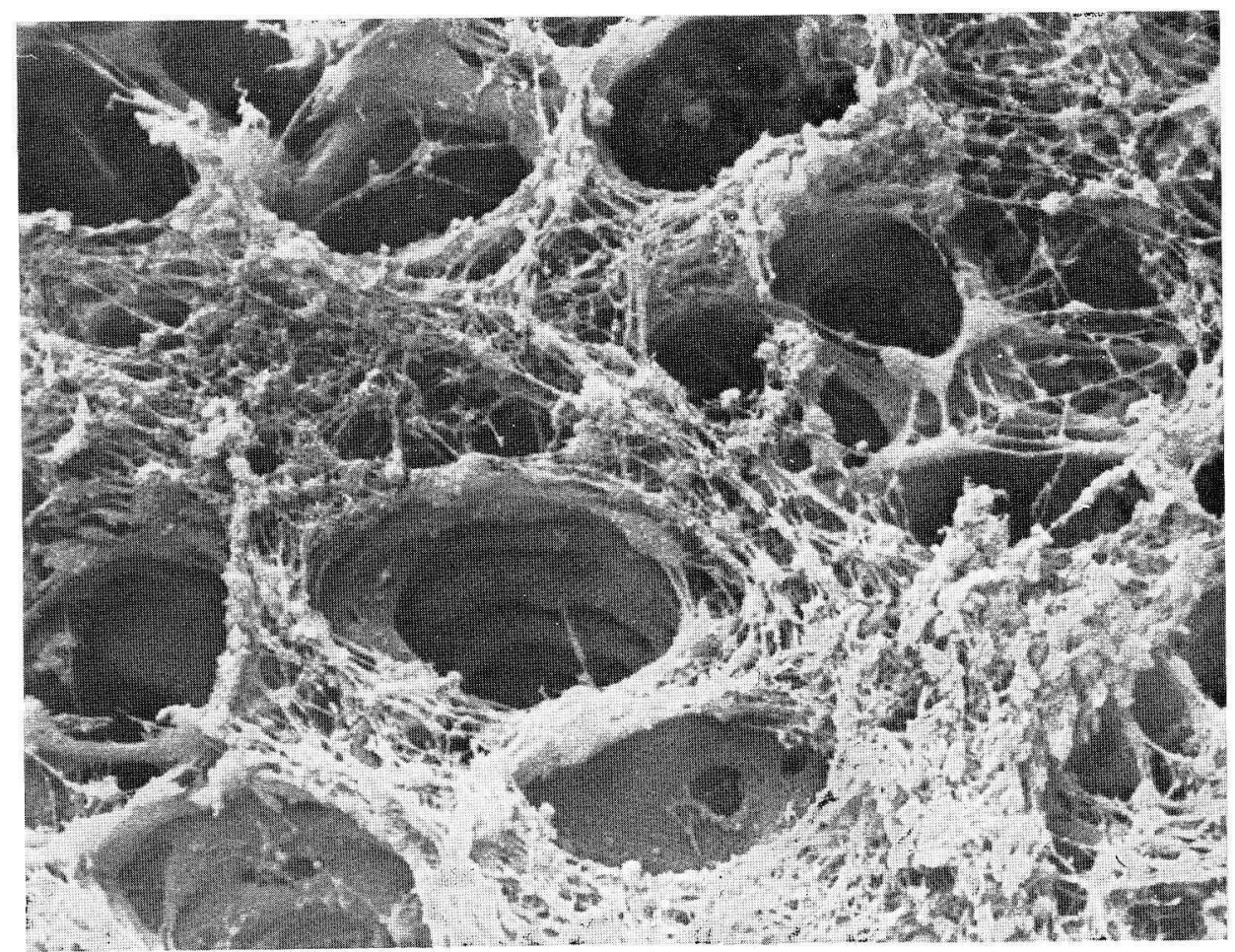

Fig. 7. Lower surface of the otolithic membrane of the utricular macula. The cavities are separated by a wall with small perforations. The cavity rims are covered with fine fibrils. $\times 5,700$

The findings on the cell-hair-tectorial membrane arrangement of the basilar papilla revealed by the present SEM study fully support the findings of previous TEM studies (Jahnke, Lundquist and WersälL, 1969; Takasaka and Smith, 1971; Dohlman, 1971). The longest hairs and the fine fibrils which connect the tectorial membrane and the supporting cells appear to work together in shearing the sensory hairs when vibration stimulates the basilar papilla.

On the otolithic membrane of birds' inner ear RosenHall (1970) reported that it did not cover the entire surface of the maculae and that there was no statoconia on the gelatinous membrane at the periphery of the membrane. Although these findings were not confirmed in the present study, the lower surface of the otolithic membrane showed structural differences between the peripheral and the central portions.

A previous TEM study of the squirrel monkey (IGARASHI and Kanda, 1969) showed a zonal structure of the otolithic membrane: an otolithic zone, a rod-shaped cupular zone 1, a diffusely dense cupular zone 2 and a subcupular zone. In the present 
study, the central portion of the otolithic membrane of the pigeon could be divided into, 1) an otolith layer, 2) a layer of cavities made of flat walls or meshes of thick rods and 3) a layer of fine fibrils which connects the otolithic membrane with the microvilli on the supporting cells of the macula. Contrary to marked structural differences in the tectorial membranes, the otolithic membranes of the pigeon and the guinea pig show remarkable resemblance (unpublished data).

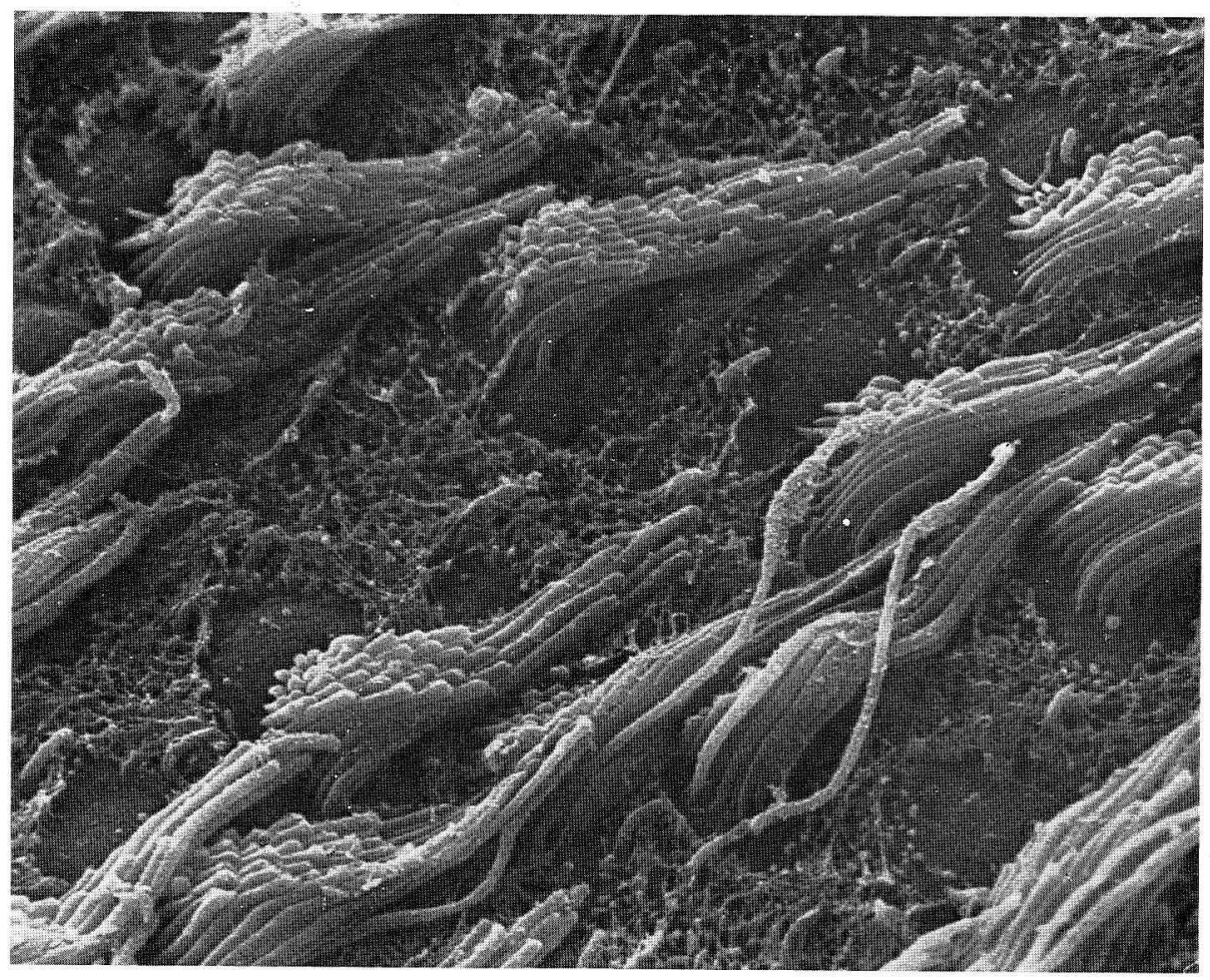

Fig. 8. Surface view of the macula utriculi after removal of the otolithic membrane. The hair bundles on the sensory cell surfaces are surrounded by many microvilli. Fine fibrils are attached to these microvilli. The hair bundles appeared to be bent down as a result of the present preparation. $\times 5,700$

The present study shows that under the otolithic membrane of the pigeon, each hair bundle of the sensory cells is surrounded by fine fibrils and projects upwards into a cavity of thick gelatinous layers and the hairs themselves have no direct connection with the statoconia. In no instances were any detached hairs found on the under surface of the otolithic membrane, nor were there any shallow imprints indicating the insertion of sensory hair tips. These facts indicate that there was no direct connection between the otolithic membrane and the sensory hairs in the vestibular maculae.

Because the otolithic membrane was composed of a loose texture with meshes and holes, it is possible that the endolymph might permeate the otolithic membrane and come in direct contact with the surface of the sensory hairs. 
The author would like to mention here that the above SEM study was made using material prepared by drying. The structures observed-such as the fine fibrillar structure, the cavities on the underside of the otolithic membranes, the canal system in the tectorial membrane and so on-might be very different in the living state of the animal.

Acknowledgment. The author is deeply indebted to Prof. Jun-Ichi Suzuki (Teikyo University) and Prof. Tsuneo Fujita (Niigata University) for their help and encouragement in this study. My sincere thanks are also due to Mr. Kenji Matsumoto (Nissei Sangyo Co., Ltd.) for his technical assistance. Mr. David Telke helped to prepare the manuscript.

\section{ハト内耳の蓋膜および耳石膜の走查電子顕微鏡による観察}

\section{星 野 知 之}

ハト内耳の蓋膜と耳石膜を走査電子顕微鏡で観察した. とくにこれらの膜と感覚細胞 との接続に注目した.

1. 蝸牛の感覚細胞表面にある感覚毛束 こまれており, 感覚毛の中でもっとも長いものの先端がこのくぼみのふちにささって いる．感覚細胞をとりかこえでいる支持細胞の表面とこのくぼみのふちとは, 細い線維 状の構造物によって結ばれている.

2. 前庭平衡斑の感覚毛束は, 細い線維状の構造物につつまれて耳石膜下面のくぼ みに入っている. 感覚毛の先端と耳石膜との接続は 証明しえなかった. しかし 感覚細 胞と耳石膜とは, 支持細胞表面にある線維状構造物によってつながれていると考えられ た.

\section{References}

Anderson, T. F.: Techniques for the preservation of three-dimensional structure in preparing specimens for the electron microscope. Trans. New York Acad. Sci. 13: 130-134 (1951).

Dohlman, G. F.: The attachment of the cupulae, otolith and tectorial membranes to the sensory cell areas. Acta otolaryngol. 71: 89-105 (1971).

Held, H.: Die Cochlea der Säuger und der Vögel, ihre Entwicklung und ihr Bau. In: (ed. by) A. Bethe: Handbuch der normalen und pathologischen Physiologie. XI. Berlin, Springer Verlag, 1926.

Igarashi, M. and T. Kanda: Fine structure of the otolithic membrane in the squirrel monkey. Acta otolaryngol. 68: 43-52 (1969).

Iurato, S.: Submicroscopic structure of the membranous labyrinth. 1 . The tectorial membrane. Z. Zellforsch. 52: 105-128 (1960).

Jahnke, V., P.-G. Lundquist and J. Wersäll: Some morphological aspects of sound perception in birds. Acta otolaryngol. 67: 583-601 (1969).

Rosenhall, U.: Some morphological principles of the vestibular maculae in birds. Arch. klin. exp. Ohr.-, Nas.- u. Kehlk. Heilk. 197: 154-182 (1970). 
Takasaka, T. and C. A. Smith: The structure and innervation of pigeon's basilar papilla. J. Ultrastr. Res. 35: 20-65 (1971).

Tanaka, K.: A simple type of apparatus for critical point drying method. J. Electron Microsc. 21: 153-154 (1972).

星野知之

厂173 東京都板橋区加賀 2-11-1

帝京大学医学部

耳鼻咽喉科学教室
Dr. Tomoyuki Hoshino

Department of Otolaryngology

Teikyo University School of Medicine

Kaga 2-11-1, Itabashi-ku

Tokyo, 173 Japan 